medRxiv preprint doi: https://doi.org/10.1101/2020.03.07.20032052; this version posted March 16, 2020. The copyright holder for this preprint (which was not certified by peer review) is the author/funder, who has granted medRxiv a license to display the preprint in perpetuity.

It is made available under a CC-BY 4.0 International license.

\title{
1 Duration of viral detection in throat and rectum of a patient with COVID-19
}

2 Le Van Tan ${ }^{1}$, Nghiem My Ngoc ${ }^{1,2}$, Bui Thi Ton That ${ }^{2}$, Le Thi Tam Uyen ${ }^{2}$, Nguyen Thi Thu 3 Hong ${ }^{1}$, Nguyen Thi Phuong Dung ${ }^{1}$, Le Nguyen Truc Nhu ${ }^{1}$, Tran Tan Thanh ${ }^{1}$, Dinh Nguyen Huy 4 Man $^{2}$, Nguyen Thanh Phong ${ }^{2}$, Tran Tinh Hien ${ }^{1,3}$, Nguyen Thanh Truong ${ }^{2}$, Guy Thwaites ${ }^{1,3}$,

5 Nguyen Van Vinh Chau ${ }^{2}$

6 'Oxford University Clinical Research Unit, Ho Chi Minh City, Vietnam

$7 \quad{ }^{2}$ Hospital for Tropical Diseases, Ho Chi Minh City, Vietnam

$8{ }^{3}$ Centre for Tropical Medicine and Global Health, Nuffield Department of Medicine, University

9 of Oxford, Oxford, UK

10 Correspondence

11 Le Van Tan, Oxford University Clinical Research Unit, Ho Chi Minh City, Vietnam; Tel: (+84

12 28) 8384009; Fax: (+84 8) 9238904; E-mail: tanlv@oucru.org

13 Nguyen Van Vinh Chau, Hospital for Tropical Diseases, Ho Chi Minh City, Vietnam; Tel:

14 (+8428) 39238704, Fax: (+8428) 39236943, E-mail: chaunvv@oucru.org 
medRxiv preprint doi: https://doi.org/10.1101/2020.03.07.20032052; this version posted March 16, 2020. The copyright holder for this preprint (which was not certified by peer review) is the author/funder, who has granted medRxiv a license to display the preprint in perpetuity.

It is made available under a CC-BY 4.0 International license.

\section{Abstract}

16 The rapid spread of coronavirus disease 2019 (COVID-19) raises concern about a global

17 pandemic. Knowledge about the duration of viral shedding remains important for patient

18 management and infection control. We report the duration of viral detection in throat and rectum

19 of a COVID-19 patient treated at the Hospital for Tropical Diseases in Ho Chi Minh City,

20 Vietnam. Despite clinical recovery, SARS-CoV-2 RNA remained detectable by real time RT-

21 PCR in throat and rectal swabs until day 11 and 18 of hospitalization, respectively. Because live

22 SARS-CoV-2 has been successfully isolated from a stool sample from a COVID-19 patient in

23 China, the results demonstrate that COVID-19 patients may remain infectious for long periods,

24 and fecal-oral transmission may be possible. Therefore, our finding has important implications

25 for infection control. 
medRxiv preprint doi: https://doi.org/10.1101/2020.03.07.20032052; this version posted March 16, 2020. The copyright holder for this preprint (which was not certified by peer review) is the author/funder, who has granted medRxiv a license to display the preprint in perpetuity.

It is made available under a CC-BY 4.0 International license .

26 The emergence of severe acute respiratory syndrome coronavirus 2 (SARS-CoV-2) and its

27 current global spread have prompted the World Health Organization to declare a Public Health

28 Emergency of International Concern. We report the duration of viral detection in throat and

29 rectal swabs taken from a patient treated at the Hospital for Tropical Diseases (HTD) in Ho Chi

30 Minh City, Vietnam. HTD is a referral hospital responsible for receiving and treating patients

31 with coronavirus disease 2019 (COVID-19) from southern Vietnam with a population of $>40$

32 million.

33 On January 31, 2020, a 73-year-old man with a history of benign prostatic hyperplasia was

34 admitted to HTD with dry cough and breathing difficulties, but without fever. He had become ill

35 with respiratory symptoms on January 26, 2020, ten days after arrival in Vietnam from the

36 United States. Whilst travelling to Vietnam, he had two hours of transit at an airport in Wuhan,

37 China.

38 Blood tests on hospital admission showed an elevation of white cells $\left(22,9 \times 10^{3}\right.$ cells per cubit

39 millimeter), but others parameters (platelet and hematocrit) were in normal ranges (data not

40 shown). His chest radiographs obtained on admission showed bilateral infiltrates (Supplementary

41 Figure 1). The patient was empirically treated with a combination of antivirals and antibiotics,

42 and received supplemental oxygen through an oxygen mask.

43 On February 1, 2020, a throat swab collected on admission from the patient was positive for

44 SARS-CoV-2 by reverse-transcription polymerase chain reaction (RT-PCR) (Supplementary

45 Table 1), followed by sequencing of the amplified product to confirm the result. Testing for other

46 pathogens (routine bacterial culture and influenza A/B viruses) were negative.

47 His clinical condition improved, and from February $9^{\text {th }}$ he no longer required supplementary

48 oxygen. However, follow-up throat swabs remained positive for SARS-CoV-2 by real-time RT- 
medRxiv preprint doi: https://doi.org/10.1101/2020.03.07.20032052; this version posted March 16, 2020. The copyright holder for this preprint (which was not certified by peer review) is the author/funder, who has granted medRxiv a license to display the preprint in perpetuity.

It is made available under a CC-BY 4.0 International license.

49 PCR (1), until day 11 of hospitalization (i.e. day 16 of illness) (Figure 1). Rectal swabs were RT-

50 PCR positive until day 18 of hospitalization (day 23 of illness). Additionally, a plasma sample

51 collected on day 2 of admission was weakly positive; urine samples were negative (Figure 1).

52 The patient was discharged with full recovery on February 21, 2020 after 21 days of

53 hospitalization.

54 Since his arrival in Vietnam, the patient had stayed in a hotel in Ho Chi Minh City, and had

55 sought for medical treatments at private clinics before hospital admission. A total of 14 close

56 contacts were identified and followed for 14 days, but none had signs of respiratory infections,

57 and their throat swabs collected on day 14 of quarantine were RT-PCR negative for SARS-CoV-

582.

59 Long duration of viral detection in throat swabs by RT-PCR has been reported in a case series

60 from China (2) and a patient in the US (3). Together with the recent success of SARS-CoV-2

61 isolation in cell culture in a stool sample of a COVID-19 patient in China (4), our finding on the

62 persistent PCR positivity in rectal swabs raise concerns about the possibility of fecal-oral

63 transmission of SARS-CoV-2.

64 Collectively, our report shows the persistence of PCR positivity in throat and rectum of a patient

65 with COVID-19, which may potentially indicate persistent viral shedding. As such COVID-19

66 patients may remain infectious for long periods, and fecal-oral transmission may be possible.

67 Therefore, our finding has important implications for infection control. 


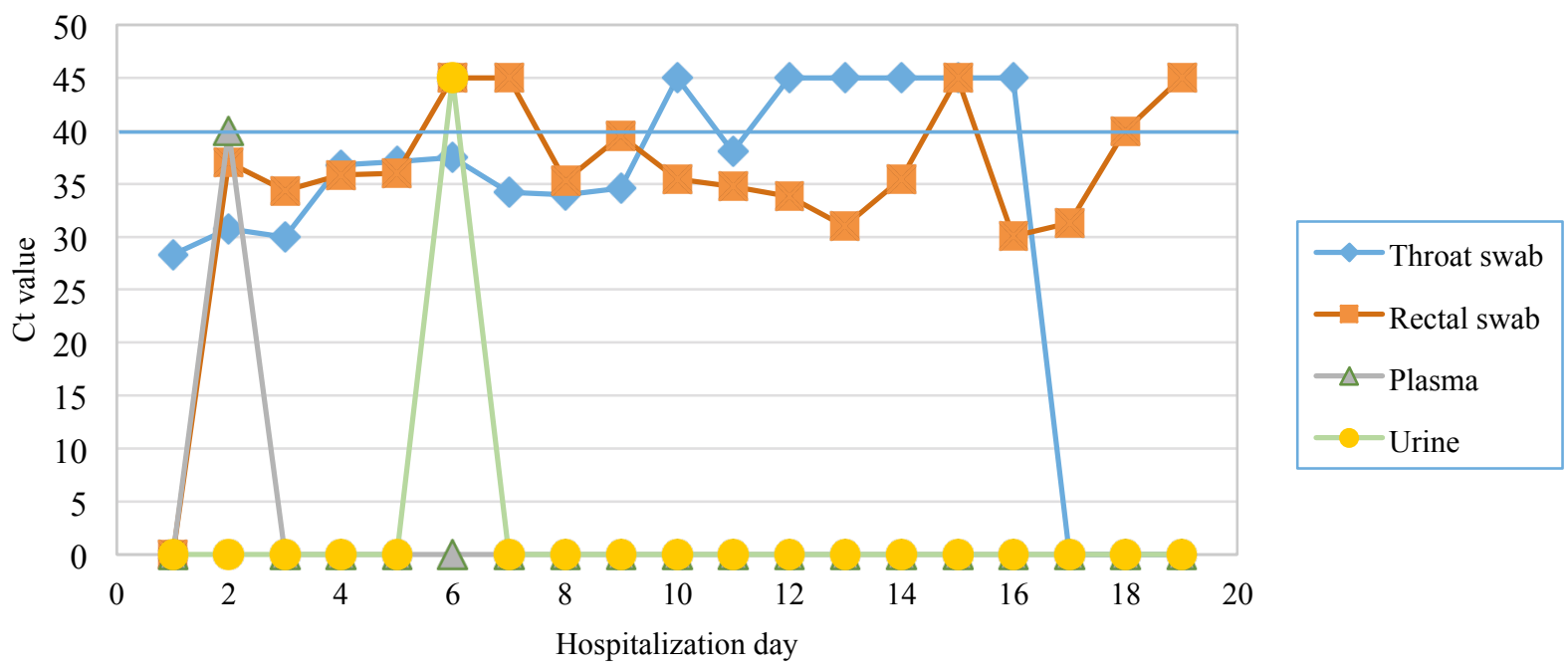

Figure 1: Results of real-time RT-PCR analysis of serial samples

Note to figure 1: a Ct value of 0 indicates no samples available for RT-PCR analysis. Ct value of 40 is the cut-off of assay detection limit (blue line). A Ct value of 45 represents for a negative real-time RT-PCR result. 
medRxiv preprint doi: https://doi.org/10.1101/2020.03.07.20032052; this version posted March 16, 2020. The copyright holder for this preprint (which was not certified by peer review) is the author/funder, who has granted medRxiv a license to display the preprint in perpetuity.

It is made available under a CC-BY 4.0 International license.

\section{Acknowledgements}

This study was funded by the Wellcome Trust of Great Britain (106680/B/14/Z and

204904/Z/16/Z).

We thank Pham Thi Ngoc Thoa, Tran Nguyen Phuong Thao, Tran Thi Lan Phuong, Tran Thi

Thanh Tam, Huynh Thi Kim Nhung, Ngo Tan Tai, Vo Trong Vuong, Le Kim Thanh, Le Nguyen

Truc Nhu, Nguyen Thi Han Ny, Motiur Rahman and Evelyne Kestelyn for their

laboratory/logistic support.

Ware indebted to the patient for his participations in this study, and all the nursing and medical staff at Ward D of the Hospital for Tropical Diseases who provided care for the patient and helped collect clinical data. 
medRxiv preprint doi: https://doi.org/10.1101/2020.03.07.20032052; this version posted March 16, 2020. The copyright holder for this preprint (which was not certified by peer review) is the author/funder, who has granted medRxiv a license to display the preprint in perpetuity.

\section{References:}

1. Corman VM, Landt O, Kaiser M, Molenkamp R, Meijer A, Chu DK, et al. Detection of 2019 novel coronavirus (2019-nCoV) by real-time RT-PCR. Euro Surveill. 2020;25(3).

2. Zou L, Ruan F, Huang M, Liang L, Huang H, Hong Z, et al. SARS-CoV-2 Viral Load in Upper Respiratory Specimens of Infected Patients. N Engl J Med. 2020.

3. Holshue ML, DeBolt C, Lindquist S, Lofy KH, Wiesman J, Bruce H, et al. First Case of 2019 Novel Coronavirus in the United States. N Engl J Med. 2020.

4. Zhang Y, Chen C, Zhu S, Shu C, Wang D, Song J, et al. Isolation of 2019-nCoV from a Stool Specimen of a Laboratory-Confirmed Case of the Coronavirus Disease 2019 (COVID-19). China CDC Weeklu. 2020;2(8):2. 


\section{Supplementary Materials:}

Supplementary Table 1: List of oligo sequences used for initial detection of SARS-CoV-2 in admission throat swab of the patient

\begin{tabular}{|c|c|l|l|}
\hline Oligonucleotide ID* & Sequence (5'-3') & $\begin{array}{l}\text { Gene } \\
\text { target }\end{array}$ & $\begin{array}{l}\text { Expected } \\
\text { product }\end{array}$ \\
\hline CoV_F_M & GGTTGGGATTATCCTAAATGT & ORF1 & $440 \mathrm{bp}$ \\
\hline CoV_R_M & GCATCGTCAGAGAGTATCATC & ORF1 & \\
\hline
\end{tabular}

Note:

*Modified based on pan-coronavirus primers described elsewhere (Methods in Molecular Biology, vol. 454: SARS- and Other Coronaviruses, 2008). Sequencing of amplified product was carried using the PCR primers. 
Supplementary Figure 1: Chest radiograph taken on admission (January $\left.31^{\text {st }}, 2020\right)$ showing bilateral infiltrates 